\title{
Bolsheviks' Encounter with the Mexican Revolution
}

Daniela Spenser

\begin{abstract}
The encounter of Bolshevik leaders and militants with Mexico during the 1920s was determined by the vagaries and evolvement of both revolutions. What appeared initially as a possible reinforcement of the revolutionary potential of both in a world engulfed in interstate conflicts and imperial domination, turned by necessity and ideology into the national and nationalist preservation of sovereignty, subordinating that revolutionary potential to the strengthening of the state.
\end{abstract}

KEYWORDS: Mexican Revolution. Bolshevik Revolution. Michal Borodin. Stanislav Pestkovsky. Alexandra Kollontai.

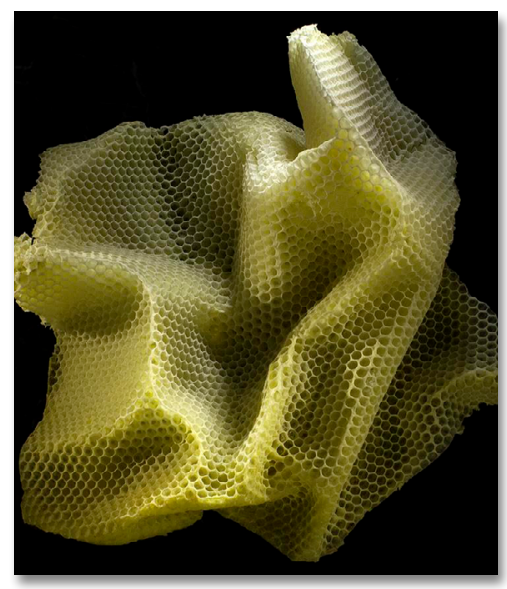

\section{O encontro dos bolcheviques com a revolução mexicana}

\section{Daniela SPenser}

Ph.D. in History. Senior Researcher and Professor, Centro de Investigaciones y Estudios Superiores en Antropología Social (CIESAS), Mexico City. She is the author of works on the history of Mexican and Latin American communism and studies of the cold war.

E-mail: daniela.spenser@gmail.com
RESUMO: O encontro dos líderes e militantes bolcheviques com $\mathrm{O}$ México, durante a década de 1920, foi determinado pelos imprevistos $e$ evolução de ambas as revoluções. O que parecia inicialmente como um possível reforço do seu potencial revolucionário num mundo envolvido em conflitos interestatais e dominação imperial, transformou-se por necessidade e ideologia em preservação nacional e nacionalista da soberania, subordinando aquele potencial revolucionário ao fortalecimento do estado.

PALAVRAS-CHAVE:

Revolução

Mexicana. Revolução bolchevique. Michail Borondin. Stanislav Pestkovsky. Alexandra Kollontai.

RECEBIDO EM: 04/06/2017 APROVADO EM: $28 / 11 / 2017$ 


\section{INTRODUCTION}

In February of 1918, the agrarian leader from the Mexican state of Morelos, Emiliano Zapata, wrote to his friend, Genaro Amezcua:

We would gain a lot, human justice would gain a lot, if all the peoples of our America and all the nations of old Europe were to understand that the cause of Revolutionary Mexico and the cause of Russia are and represent the cause of humanity, the supreme interest of all the oppressed peoples. (BARTRA, 1986, p. 320)

Zapata perceived "the visible analogy, the pronounced parallelism, the absolute parity, to put it better, that exists between the Russian movement and the agrarian revolution in Mexico" (Bartra, 1986, p. 320). To Zapata and others the Bolshevik revolution was attractive because it seemed to offer the same intense feeling of community which was at the core of their struggles. The anarchist Ricardo Flores Magón in March 1918 described the Russian revolution as:

a movement that has to spark, whether those
ingratiated with the current system of exploi-
tation and crime like it or not, the great world
revolution that is now knocking on the gates
of all the peoples; the great world revolution
that will introduce important changes in the
way in which human beings live with one an-
other. (BARTRA, 1986, p. 321).

Indeed, in 1918 labor organizations, artisans, and intellectuals of the city and the countryside, without knowing the details saw the Bolshevik Revolution as having the same goals as the Mexican. For the libertarians and agraristas, the soviets or workers' councils exemplified direct action, individual freedom, and the destruction of the bourgeois state.

However, in the process the trajectory of the Bolshevik revolution took roads different from what its admirers had anticipated. The Mexican anarchists and the Zapatistas became wary of the Bolshevik position in relation to the role of the state, workers' democracy and land reform, understood as the right of those who till the soil to have land. For the anarchists, the revolution turned into tragedy; for Flores Magón, the dictatorship of the party 
became a tyranny and the economic measures of radical communism, whereby food was taken by force from the countryside, and taken to the cities to feed the urban population, and the dismantling in one sweep of the market, did not bring either freedom or well-being. In 1921 Flores Magón, then lingering in jail in Missouri for his radical activities in the United States, no longer saw any future in Bolshevism. He foresaw that: "The collapse of Lenin and Trotsky's dictatorship is only a matter of time, and the workers of the world should be prepared to face that failure with serenity" (BARTRA, 1986, p. 322). Alongside such skepticism, other sectors of the Mexican society looked to the Bolshevik Revolution as a possible alternative to the legal rigmarole that the national revolution was becoming (BARTRA, 1986; LOMNITZ, 2014).

This article -- based on research in the Soviet archives after they became accessible in the 1990s, on repositories in Mexico and the literature that has been published since then, uses biography as a methodological tool. It is divided into several historical stages, represented by three individuals who arrived in Mexico at particular junctures during the development of the Mexican and the Bolshevik revolutions during the 1920s; it accounts for what they did, saw, thought and felt, and what effect their experience might have had on their lives upon their return to the Soviet Union. I shall refer to Mikhail Borodin, which was the alias of Mikhail Gruzenberg, born in 1884 in Byelorussia and died in prison in 1951; to Stanislav Pestkovsky, of Polish noble origin, born in 1882 and vanished in 1937 during the anti-Polish purge in the Communist International; and to Aleksandra Kollontai, born in 1872 in St. Petersburg and died in 1952 in Moscow in her bed. The aim of the article is to examine the interaction between individuals, the context in which they happened to act, and how what they did and thought in turn shaped the milieu in which they lived.

\section{THE FIRST STAGE}

After the founding of the Communist International, known also as the Third International, or Comintern, in March 1919 in Moscow, the Bolshevik leaders spread the news of its existence and its ideas beyond Europe with greater vehemence, determination 
and resources than had been expended with the expansion of the First and Second Internationals. The original idea of stimulating revolutionary struggles in Europe that would be followed by movements in the rest of the world changed as a result of the failed attempts at revolutions in Europe, e.g., in Germany and Hungary, and the social turbulence in the countries that were on the periphery of the capitalist system. Even though Latin America was not contemplated within the revolutionary horizon of the Bolsheviks in the first months of the revolution, it figured in Lenin's calculations as a region that, under the yoke of US imperialism and in the category of countries such as China, Turkey and Persia, had awakened to political life. Mexico, more than any other country in the hemisphere, appeared to be a favorable terrain for planting ideas on communism, for organizing communist parties, and adhering them to the International (STERN, 1990; WEINER, 1997; LAZITCH; DRACHKOVITCH, 1972; ELLEY, 2002).

When Lenin sent Borodin to the United States and Mexico, Borodin was a faithful interpreter of Lenin's ideas. His task was to establish a party in the image and likeness of the Bolshevik Party: centralized, disciplined, and capable of serving as a national branch of the party of the world revolution, the Comintern. Borodin, then thirty-five years of age, left Moscow in April 1919 with a Mexican diplomatic passport under his real name, Mikhail Gruzenberg, which he had acquired in the chaotic situation of 1918 in Moscow when the office of the Mexican consulate was seized by a group of soldiers who removed the rubber stamps and blank passports. One of the passports was probably falsified to adapt it to the traveler's needs. In his luggage Borodin was carrying the renowned jewels of the Russian imperial family that the Soviet government attempted to convert to cash to finance the formation of communist parties (AHSRE, 1919).

Thanks to a wealth of news that circulated in the United States on the Mexican Revolution, reported by US journalists who traveled to and from Mexico, Borodin was sufficiently informed on recent Mexican history to the extent that he knew whom to contact once he arrived in the capital. There he met a group of foreign socialists who supplemented his lack of understanding of Mexico 
with their own interpretations. Initially, Borodin was presented as the possible ambassador from Soviet Russia. When he got to know them better, he revealed that he was the representative of the Communist International.

Borodin's objective was to initiate relations with the Mexican government to establish diplomatic relations with Soviet Russia and at the same time look into the possibility of founding a communist party with the goal of spreading its influence throughout Latin America. The two objectives were not in contradiction with each other. Starting or enlarging minuscule trade relations, supplying Soviet Russia with foodstuffs and raw materials, thus fortifying it in the process, had practical as well as ideological significance. Despite the fact that the Argentinean socialists and labor movement were better organized, Mexico was in the orbit of US imperialism, and its workers' proximity to the US labor movement and the close relations between the two had greater potential to become a focus of a continental revolutionary movement (ROY, 1964; ULDRICKS, 1979; GÓMEZ, 1964; SHIPMAN, 1993).

Borodin arrived in Mexico after the First National Socialist Congress was held in Mexico City in August and September 1919. The organizers of the congress - the trade unions and groups of various persuasions, the anarchists among them - called upon the participants to join the Second International, rather than the Comintern, which was largely an unknown entity. Whereas Borodin did not succeed in establishing diplomatic relations with Mexico because it was locked in various disputes with the United States, the combination of his impressive and persuasive personality and Mexico's hopeful but unfulfilled promises of its revolution led a few socialists under his influence to change the party's name to the Mexican Communist Party, and it became a branch of the Third International. Before leaving Mexico in December, Borodin bestowed upon the microscopic group that he helped to create the pompous status of the "Latin US Bureau of the Third International" and it became an extension of the bureau that the Comintern had established in Berlin and in Amsterdam to bring the European communists closer to Moscow; with little regard for the opinion of others, he selected delegates to the Comintern's Second Congress, called for July 1920 (CARR, 1992; KHEIFETS; KHEIFETS, 1994/95). 
The fragility of the Mexican Communist Party's foundations notwithstanding, on his return to Moscow with several supposed delegates to attend the congress of the Comintern, in an era of boundless voluntarism and revolutionary optimism, Borodin carried the encouraging news that there existed possibilities for the growth of the communist movement in Latin America. Mexico was a topic of discussion during the deliberations. It was mentioned by the US communist delegates Louis Fraina and John Reed, who had had first-hand experience of the Mexican Revolution in 1913, having participated in fighting alongside Pancho Villa. Fraina, who was one of the first to publicize Lenin and Trotsky's works in the United States, talked about the political turbulence in Mexico and of the danger that the struggles in Latin America posed for US capitalism, although he minimized the complexity of the Mexican revolution and in the end described Mexico and Latin America as passive victims of the oppressor's aggressiveness. They were said not to have offered resistance to US economic and political hegemony (BUHLE, 1995).

Reed, on the other hand, spoke of the influence of the Mexican revolutionaries, who were said to have created a popular government that was democratic, rather than proletarian, and that wanted to keep the wealth of Mexico for the Mexicans and tax the foreign capitalists. Fraina and Reed presented two different perspectives on Mexico, but both were encouraging in terms of the possibilities for developing a revolutionary movement that would be capable of challenging US imperialism, although they offered no details as to how it would develop. These reports and opinions concerning Mexico created the impression of a country with the potential to develop a communist movement both domestically as well as in the rest of Latin America. One of the self-proclaimed Mexican delegates, the US draft dodger Charles Phillips ${ }^{1}$, had the good fortune to be received by Lenin and was charmed by the Soviet leader. Lenin had some vague notions about Mexico, its bourgeois revolution and the restive peasants demanding land. Phillips wrote in his memoirs:

1 Charles Phillips, alias Jesús Ramírez. 
Could he be of help? His information on the
country was--frankly--fragmentary. He had
not known that much of the peasant popu-
lation was Indian. Did we have any litera-
ture written in indigenous dialects? (No. The
Indians were illiterate). Then we would have
to recruit Indian speakers. Those Indians, he
said, should be your number-one objective in
the countryside. The rest of his remarks em-
phasized Mexico's strategic location in the
Western Hemisphere. Everything that he said
made a contribution, and it all revealed the
same simple, forceful logic. (PHILLIPS, 1920,
p. 5-8).

In September 1920, the Comintern decided to send three envoys to Mexico in charge of continuing the work of organizing communism initiated by Borodin in November 1919: Charles Phillips, the Greenwich Village Socialist, Louis Fraina, the US socialist, and Sen Katayama, a veteran of Christian Trade Unionism and Japanese Socialism. All of them made an indelible impression on Lenin during the Congress in Moscow.

In sending three agents to Mexico in 1921, the Comintern bestowed upon the Latin American country an importance granted to few others and placed it in a similar rank as China and Eastern nations adjacent to Soviet Russia, all despite that Mexico did not have the same strategic location. By the time they left Mexico a year later, they had abandoned the idea that the project that emanated from the October Revolution was universal and that it could be adapted to whatever the national conditions might be. They learnt that post-revolutionary Mexico did not fit the Soviet formula that the working class had the capacity to lead the rest of the laboring classes, with the communist party as a vanguard. For much of the working population, the Mexican revolution, encapsulated in the State and sanctioned in the 1917 Constitution, was in progress and harboring a promise yet to be fulfilled. In proclaiming that the power of the revolutionary elite emanated from the sacrifice that the revolution exacted for having triumphed over the old regime, the Comintern in effect sanctified the revolution in many layers of Mexican society. 
In view of the analysis that the Comintern made regarding the failings of its organizational work in Mexico, and the modification of its world outlook, from envisioning the imminent collapse of capitalism to its survival without meaning its recovery, the Third International changed the tasks it assigned to the communists to bring down the economic, political and social system that sustained capitalism in order to take power. The tactic was called bolshevization and was vigorously implemented during the $1920 \mathrm{~s}$ until a crisis occurred in the Soviet Union's international relations, in which several countries broke ties with Moscow. The world economic crisis at the end of the decade compelled the Soviet Union once again to change its line from coexistence to confrontation with the capitalist nations. The period was characterized by Lenin's death, in January 1924, and Josef Stalin's rise to prominence in the party. Gradually the Comintern was transformed into the international arm of the Bolshevik Party and the controversies in the Soviet Union were transferred, albeit not mechanically, to the national branches of the Third International for their adoption, creating long-lasting fragmentations and hostilities between Stalinists and Trotskists and many shades in-between.

\section{THE SECOND STAGE}

When in 1924 Mexico reestablished diplomatic relations with the Soviet Union, Stanislav Pestkovsky became the ambassador during the day, and Comrade Andres, representing the Comintern for all of Latin America the rest of the time. Pestkovsky stayed in Mexico for two years. His revolutionary activities brought the displeasure of the US government, the Mexican government, and of Mexico's organized labor which the government supported and on which it relied to keep the restive labor force in line. Pestkovsky was recalled in 1926 before he was expelled by the Mexican government.

We can only surmise regarding Stalin's motives to agree to Pestkovsky's nomination to the post of Ambassador to Mexico. Did the general secretary also see the strategic importance of the opening of an embassy in such a close proximity to the United States, 
or did he place a greater weight on the fact that Pestkovsky, who had only shortly before belonged to an opposition group considered a deviation, was better out of the way? After all, such prominent Bolsheviks as Angelica Balabanova, Christian Rakovsky, Alexandra Kollontai, among others, were sent abroad when there was evidence that they were opposed to the Bolshevik party line.

Pestkovsky subscribed to the view that Mexico was a semicolonial country dominated by foreign capital, and still in the grips of the remnants of feudalism, which precluded the development of internally generated, autonomous, liberating social forces. Mexican efforts at economic rebuilding represented an unsuccessful battle against imperialism, the nature of which underscored other struggles, including the state-Church conflict, the state's battle over the control of the labor unions, the anarchists' and labor's efforts to remain independent of both, and the state's program for land reform. All these struggles, fatally subordinated to the forces of imperialism, would eventually be lost despite the fact that Mexico displayed an independent and leading role in Latin America in establishing diplomatic relations with the Soviet Union, and served as an example to the rest of the continent.

Pestkovsky, like the Comintern, believed that the Pan-American union, organized by the US Federation of Labor, was a tool of Yankee imperialism and should and could be replaced by a confederation controlled by those governments and labor unions which shared anti-US sentiments. Pestkovsky had originally believed that the Mexican president would endorse his initiative, realizing later that the government walked a tight rope when it came to the United States, and would not risk US economic and military sanctions (PESTKOWSKI, 1961).

Indeed, by mid-1920s the Mexican government was locked in a legal and political controversy with the US government and US property holders over who had particular rights under the 1917 Constitution, a conflict which was perceived as a threat to Mexico's sovereignty. Whereas one segment of the labor movement was held hostage to the state-sponsored labor confederation in exchange for improvements in salaries and some labor conditions, dispersed labor unions held on to their autonomy at 
a cost in loss of employment at best, and of life, at worst. There were members of the communist party at the helm of the agrarian movement and communist muralists covering the walls of public buildings with revolutionary themes. (CARR, 1976).

Before his departure from Europe, Pestkovsky met the recently elected Mexican president, Plutarco Elias Calles, in Berlin. He may have believed that he spoke to a fellow-traveler, at least as far as anti-imperialism was concerned. Even though Pestkovsky encountered a cautious president, and this may have therefore tempered the Russian's optimism because of the oppressive regimes governing most of the Latin US countries, the ambassador injected revolutionary élan into the routine of his diplomatic work once he had settled in Mexico in October 1924. He believed that in some ways the Mexican government was a marionette of imperialism, and that the working class deserved his professional attention. He also thought, however, that the petty-bourgeois government could in due course be neutralized by a swelling of the rank and file, and in due course overthrown.

Pestkovsky maintained a lively contact with Mexican officials, the diplomatic corp and the intelligentsia. His visible work was actively organizing celebrations to mark Lenin's death, the Bolshevik victory and May Labor Day. His parties at the embassy became the talk of the city. He hosted the diplomatic corps, as well as the workers and communists. On occasion, Diego Rivera dropped in straight from his scaffolding, still covered with paint. Pestkovsky showed films and served tea afterwards. He routinely invited the Mexican president, who consistently declined the invitations. The president pled that he had too much work, or that he had conflicting engagements, or that the invitation arrived too late. Evidently, the president did not want to be seen at the Soviet embassy for fear of how this would be interpreted. Other political leaders had no such qualms, and became regular visitors to the embassy, or at least visited it occasionally. Beginning in March of 1925, five months after his arrival in Mexico, Pestkovsky began writing a diary.

Such diaries, routinely written by Soviet diplomats worldwide, consisted of entries of official conversations routinely conducted 
with foreign diplomats. Pestkovsky's diary, however, did more than follow official instructions from the Commissariat. On the basis of his understanding of Mexico, a combination of what he had learned before his arrival and on his limited experience later, and of world events, with the Soviet Union placed at its center of it, he wrote about his numerous contacts with other diplomats and Mexican functionaries, and as someone who believed his interventions would mold the world toward the Soviet regime's supremacy while preserving peaceful coexistence (PESTKOWSKI, 1961).

Closest to his heart, however, were the topics of revolutionary propaganda and organization. His life was entwined with the party, and with counseling the Mexican communists. He provided generous funds to finance the Mexican Communist Party's newspaper, as well as a combative organ of the Anti-Imperialist League. The newspapers that Pestkovsky subsidized criticized not only "Yankee imperialism," but also the labor confederation, the Confederación Regional Obrera de México, CROM, supported by the government mostly because of its subservience to the government and to the US Federation of Labor. It was not long before the Confederation became wary of the Soviets in Mexico, having witnessed how the one union whose control it coveted, the railway syndicate, was gradually falling under the sway of the communists, guided politically and supported financially by the Soviet embassy.

The CROM leaders began a campaign to pressure Calles into moving beyond rhetoric. They wanted him to expel Pestkovsky from Mexico. CROM's primary complaint was the Communists' growing influence in the railway confederation. This was underscored in 1925 when it created a rival organization of railway workers, which few workers joined. Although the railway workers had been ignoring the CROM, they opposed President Calles's attempts to reorganize the railway company. One of Calles's economic goals was to initiate the company's economic rehabilitation. Damaged during the revolution and by subsequent rebellions, the railway was further weighed down by debts and unresolved labor conflicts. Calles's plan to restore the company began with his attempt to reorganize its budget. A detailed study had shown that while in 1909 the company's profits were at 41\%, in 
1926 they had fallen to $6 \%$, and that while in 1910 the average salary had been 56.13 pesos a month, in 1927 it had risen to 124.78 , an increase of $225 \%$. The government wanted to return the railways to private ownership to unburden itself of an enormous debt. The deal did not go through, however, because a condition of purchase by the prospective buyer was to reduce the number of workers and decrease their salaries. The government would not agree to this for political reasons. Instead, the railways came under the control of the Ministry of Communications, and the workers became federal employees, barred from striking. The new administration implemented an adjustment of salaries and manpower, but in June 1926 the railroad mechanics laid down their tools anyway, and the company promptly laid them off. The CROM president, and Minister of Industry, Labor and Commerce, Luis Morones, pronounced the strike illegal, bringing in scabs and troops to break it up. The Soviet Embassy had supported the railway workers in their resistance to the reorganization of the company, as well as the workers' motion to go on strike, and arranged for a provision of fifty thousand rubles (US $\$ 25,000$ ) for the workers, to be sent by the Soviet Union's Railway Workers.

The money reached its destination in March 1927. It enabled the workers to move to new, safer and more spacious headquarters, which provided a haven for families who could no longer pay their rents because of the strike. The funds also helped support a soup kitchen and financed publication of an information bulletin for as long as the money lasted. Once the funds dried up, the workers were forced to evacuate the building and economic hardship weakened the strike. One-by-one, the workers went back to work, convinced that they could not fight both the company and the government. The strike was finally defeated in the spring of 1927 (BARRIOS, 1978).

It was the Mexican Communist Party, however, that consumed most of Pestkovsky's energy. The party suffered from internal divisions. Each faction vied for leadership of the Central Committee, and Pestkovsky's involvement in its affairs added to an already polarized organization. The differences between one faction and another manifested themselves in the perennial problem relative 
to the party's existence, and lack of a social base. While contact with labor and peasant organizations gave the communist leaders political authority, the struggle for ascendance over the popular movements was at the core of its fragmentation and internal strife.

The importance of workers was by far outweighed by that of the peasants. Their movement for land had enormous political significance, not only because of sheer numbers, but also because of their explosive resistance to the power of the landholders, foreign interests, and therefore, in theory at least, to imperialism. it is no wonder, then, that the party sought to bring the peasants under its control. Despite the fact that the peasant leagues had been affiliated with the Peasant International, one branch of the Comintern, since 1923, the peasants and their leaders were more interested in securing land than in engaging in political activities unrelated to their immediate goals.

In view of his activities, trouble was not long in coming for the Soviet Ambassador. The first salvo was launched despite the fact that Pestkovsky had nothing to do with its putative cause. The occasion was the Soviet Commissar Chicherin's speech in Moscow to the Party Central Committee in March 1925. Assessing the state of foreign relations in the context of the United States' denial of recognition of the Soviet Union, Chicherin remarked:

We have succeeded in reestablishing diplomatic relations with a neighbor of the United States, Mexico, which gives us a political base on the new continent. The Mexican government is based on the rightist trade unions and the petty bourgeoisie. The Soviet Republics are extraordinarily popular in Mexico. Our plenipotentiary representative, comrade Pestkovsky, met with the most enthusiastic reception in Mexico, constantly experiencing the most friendly, enthusiastic attitude toward the Soviet Republic. Mexico gives us a very convenient base for the further extension of our ties in America (CLISSOLD, 1970, p. 87). ${ }^{2}$

2 Vadillo to SRE, Moscow, 30 April 1925, ASRE, 18-22-86; "Intemperancias Bolshevistas," Excélsior, 5 May 1925; "Las Declaraciones del C. Presidente se Han Recibido Bien" by Arthur Mackel, 6 May 1925; "El Ministro de la Rusia Roja Dió Explicaciones Ayer a Nuestro Gobierno,"8 May 1925, Excélsior; Weddell to 
Chicherin's observation came at a sensitive time, coinciding with the US ambassador's notes of protest to the Mexican government after the administration had intensified the process of agrarian reform. The leading Mexican newspaper interpreted Chicherin's speech as Soviet Russia's attempt to use Mexico as the operational base for its Bolshevik propaganda in the United States and Latin American countries.

Undeterred by the trouble caused by Chicherin's speech, Pestkovsky continued his work of radicalizing Mexican politics. When he learned of a military uprising planned for mid-1925, he naively believed that the moment of truth had arrived and that one wing of the military, the supposed left, should be separated from the supposed right wing, not understanding that what was really at stake were conflicts among military factions, and that whoever rebelled against the government was seen as subverting a constitutional order, and would be court-marshaled. This was indeed what happened every time during the 1920s that a military uprising took place.

The Soviet Embassy also became a lighthouse for Latin American revolutionary opposition to dictatorial regimes supported by the United States. The Cubans were opposed to Gerardo Machado, for example. The Venezuelans opposed the presidency of Juan Vicente Gomez. At the time, the Venezuelan opposition was preparing the overthrow of Gomez, and needed arms and the means to transport them to Venezuela. While, according to Pestkovsky, the government of Mexico promised the arms, the insurrectionists asked the Soviet ambassador for a ship, or at least US $\$ 7,000$ to rent one. Pestkovsky promised to inquire with his government about the possibilities of such assistance.

Pestkovsky left Mexico in the fall of 1926, ostensibly on his own initiative. Most likely, however, the Mexican president had asked him to leave before he was to be expelled. The CROM, which feared a rivalry with the communists that would include organized

Secretary of State, Mexico City, 11 February 1925, reel 83, 812.00/27508 
workers then under its umbrella, was pleased with Pestkovsky's departure, and hoped that Calles would break off relations with the Soviet Union. Despite CROM's insistence, however, the president maintained Mexico's relations with the Soviet Union. The US Department of State also favored Pestkovsky's expulsion, hoping that this would be cause for Mexico's severing relations with Moscow (KRAUZE; MEYER; REYES, 1981). However, as long as the US continued to pressure Mexico to refrain from implementing constitutional reforms, the Mexican government was conscious that breaking relations with the Soviet Union would convince the North Americans that the pressure they exerted was producing the intended result. Such pressure would weaken Mexico's sense of independent maneuvering in the international arena, the prime reason for which those relations had been established. It would also alienate Calles's allies at home, mostly comprised of the more reformist elite in the government, as well as the factions within the radical labor movement which believed that Calles was their kind of president.

\section{THE THIRD STAGE}

It was into these unsettling circumstances that the new ambassador, Alexandra Kollontai, arrived. She was preceded by her fame as a feminist, condemned by the Soviet Communist Party for her "bourgeois ideology," apparently primarily because it failed to identify the institution of private property as the foundation of gender inequality, which only a unified effort of both men and women was thought to be able to resolve. Kollontai believed that the emancipation of women workers would not take place without a revolutionary struggle, but pointed out that women had specific needs due to the bonds of tradition. Even formulated in this fashion, her ideas were rejected by the males of the party, who argued that women should join in the general revolutionary struggle. They characterized her social theory as differing from the objectives of socialist construction. After Lenin named her Commissar for Social Welfare, Kollontai drafted several bills mandating government support for maternity care in coordination with other commissariats, and 
authored several laws that established women's political and legal equality. In addition, she led a campaign to draw women out of the home and into activities and political posts. In 1922, Kollontai left her domestic posts, and Soviet Russia, after playing a leading role in the defense of trade union freedom, workers control of the factories, and party democracy. From then on, she spent her time in the diplomatic service, and writing. She would have preferred to leave government service, live in France and write her memoirs, but the party opposed this. A diplomatic career was the only alternative open to her if she did not want to join the ranks of Russian émigrés (CLEMENTS, 1979).

Several weeks before sailing to Mexico in the fall of 1926, she told the press that diplomats should abstain from carrying out propaganda or interfering in the internal affairs of the host country. She was unpleasantly surprised when, on her arrival at the port of Veracruz in December 1926, local communist workers gathered to welcome her. She refused to address them and invited only a small delegation to her hotel. On her arrival in Mexico City, there were throngs of people waiting at the railway station with banners that read "viva Rusia soviética", "viva la compañera Kollontai". She thought the demonstration inappropriate, and waited in her compartment until they all left (ORTIZ, 2012).

Kollontai's fame as a feminist brought her more trouble than satisfaction in Mexico. She was accused of amoral behavior, and of desiring only to sow the seeds of communism in Mexico and Latin America. She was smeared by a pirated edition of her short story, "Bolshiaia liubov" ("A great love"), published under the sensationalist title "Red Love." Originally published in 1923, the story was part of a collection entitled Women at the Turning Point, and was based on the author's experiences. The story told of a woman who sought self-realization through her work, over and against her husband's opinion. The writer used a sentimental and romantic plot to popularize her theories regarding female emancipation and women's liberation from bourgeois morality. Despite her efforts to stop the publication, the story came out as a cheap and sensational romance. 
However, it was of great significance that at a public ceremony a woman was accredited as an ambassador, and, moreover, one representing the Soviet Union. In her daily routine, however, Kollontai moderated her contacts with Communist Party members who visited the embassy, far too often in her view, as she noted in her diary. She did not think much of them: they tended from her perspective toward anarcho-syndicalism or reformism; some of them, she thought, were clear-headed, but most were merely enthusiastic, manifesting little or no understanding of the theoretical foundations of Marxism and communism. Their admiration for Lenin was boundless. She would have liked to be in closer contact with women, but felt constrained by the role she was assigned to play.

The attacks on her by the local and international press were disheartening and together with the altitude of the city, drained her energy. By March 1927 Kollontai resolved to leave Mexico. She left in June. Before her departure the weavers sent her a sarape, a warm blanket, with her initials. Another group of artisans brought her a coconut shell with the following engraved message: "Para la camarada Kollontai. Los imperialistas te odian, los revolucionarios te quieren. Viva en nuestros corazones la amistad de México y Rusia" ("the imperialists hate you, the revolutionaries love you, long live in our hearts the friendship between Mexico and Russia"). Despite her irritation with the hostility toward the Soviet Union, she later recalled her arrival and the welcome she received from the workers waving red flags. She felt those workers to be her comrades, and remained hopeful and firm in her belief that those workers would eventually obliterate the parasitic bourgeoisie (ORTIZ, 2012).

\section{IN CONCLUSION}

Mikhail Borodin, Stanislav Pestkovsky and Alexandra Kollontai believed that their revolution was superior to the Mexican Revolution. However, the encounters of the three with Mexico taught them that the Communist International could not correctly formulate a program for world revolution while leaving the 
proletariat of the non-European countries, subjugated as they were by imperialism, outside of its sphere of action. They each saw the importance of the peasantry as agents of change in the "semi-colonial" countries like China and Mexico.

While Borodin's stay in Mexico in 1919 was an exploration of unchartered territory, and one which yielded some striking results, his mission to China from 1923 to 1927 represented an anticipated "Eastern Route" to world revolution. In sum, he identified similar historically grounded elements at play in the two countries: an end to old regimes, that of Porfirio Díaz in Mexico in 1910, and the Chíng dynasty in China in 1911, as well as a power vacuum filled by warring factions in Mexico, and by the provincial warlords in China. The appearance of strong enough nationalist leaders capable of bringing warring factions under their direction, Venustiano Carranza in Mexico, and Sun Yat-sen in China, were thought to have led these two countries, at least, to some semblance of social democratic republicanism.

What role did Borodin's previous revolutionary activities in the United States, Mexico and Great Britain, his charismatic personality, his dynamism as an organizer and as a shrewd strategist play in Stalin's decision to appoint him as a political advisor to Sun Yat-sen? Employing the same resolve which he had applied in Mexico, but on a larger scale, Borodin reorganized the Chinese nationalists along the lines of the Russian model, and helped to promote the communists to key positions in the party, the Kuomintang. Under Borodin's direction, moreover, Bolshevik advisers established the Whampoa Military Academy. While its commander was Chiang Kai-shek, the guiding hand on the staff was a Soviet general. The Nationalist Party's program and statutes, and its agitprop art, left its Soviet imprint. When in 1927 Beijing authorities raided a Soviet compound and found a large cache of documents, the documents revealed Soviet involvement in a plan to overthrow the government. As we know, the commander in chief of the nationalist party, Chiang Kai-shek, ordered a purge of communist influence in its ranks, and Borodin fled China in haste. After his return to the Soviet Union, Borodin worked as editor of the English language Moscow News, the foreign language newspaper 
that focused upon propaganda, principally regarding Soviet life and achievements. He was arrested in 1949 during a period of anti-Semitic repression, and died two years later in Lefortovo prison (CHANG; HALLIDAY, 2005).

Pestkovsky also had to make a hasty retreat from Mexico after his involvement in the labor movement, which opposed the government's measures to streamline the railway labor union. Neither the flow of the Mexican revolution nor its international concerns could withstand the meddling of a Bolshevik in its internal affairs. But Pestkovsky was driven by his sense of duty, and probably his sense of his own importance. Despite his long revolutionary underground credentials, dating from before the October revolution and including arrests, expulsion, and exile, it appears that he did not take the necessary precautions to protect himself from the myriad of intelligence agencies which had mushroomed after the outbreak of the WWI (KATZ, 1981).

Upon his return to Moscow, Pestkovsky was assigned to work in the Comintern, and put pen to paper about Mexico. He authored a series of articles for Soviet journals, as well as two major studies, A History of the Mexican Revolutions and The Agrarian Question and the Peasant Movement in Mexico. Studying Mexican history in the context of his view that history was an explanatory chapter to politics enabled him to identify the internally generated social and political agents of change writ large, and to avoid propagandizing assertions such as: that the masses were inherently rebellious, and that their revolutionary potential could only be realized if their reformist leaders could be replaced by communist leaders. After his experience, Pestkovsky did not perceive the government's alliance with the proletariat and peasantry as sheer opportunism. He viewed it as resulting from the emergence of the popular classes in the political arena, with the peasant movement at its centre. Were to follow the Soviet model, Mexico would need to work toward a labor-peasant alliance. Peasants, after all, had been the revolutionary force there. ${ }^{3}$

3 A. Vol'skii, "Agrarnyi vopros i krest'ianskoe dvizhenie v Meksike," Na agrarnom fronte, no. 2 (February 1927), 46-59. 
Even though Pestkovsky presented a more subtle and analytical explanation of the Mexican Revolution, his ideologically-tinged articles about Mexico dominated the Stalinist Comintern press, and portrayed Mexico as the hapless victim of US imperialism, forced either to succumb to, or to participate in, a proletarian revolution. In addition to writing about the Mexican revolution and the agrarian movement, Pestkovsky was a middle level bureaucrat in the Peasant International, in the Agrarian Institute, in the Anglo-US and the Latin American lander secretariats, and in Lenin's School for cadres. In all those positions he tried to defend the specificity of Mexico without departing from Marxist orthodoxy.

However, the economic crisis that erupted in 1929 confirmed and strengthened the Bolsheviks' conviction that a capitalist crisis was the "midwife of the world revolution." When agriculture in the Soviet Union was undergoing a process of collectivization and the abolition of private ownership of land, ideologists could not concede that the organized agraristas had a progressive role in Mexico. The Mexican Communist Party, which had collaborated with them, was also condemned because it failed to appreciate, as had Pestkovsky, that the agrarian regime had not left the stage of the feudal mode of production. This interpretation of Mexico's evolution subordinated the Mexican Revolution to a Soviet teleological interpretation of history in which the country was no more than a link in the chain of events on a world scale. In 1930, as in the early 1920s, Mexico had to fit into this chain of universal history, and this meant not only an intellectual regress, but in taking the political high ground, the Soviet Union had slighted the Mexicans, leading to the breakdown of diplomatic relations with the Soviet Union, and banning of the Mexican Communist Party. It took decades for the reestablishment of relations between the two countries, and for the emergence of an intellectual understanding of each other's revolution. 


\section{REFERENCES}

AHSRE - Acervo Histórico de la Secretaría de Relaciones Exteriores. Leopoldo Ortiz to the Foreign Relations Ministry (SRE). Berlin, Germany, 29 December 1919.

BARRIOS, E. El escuadrón de hierro. Mexico City: Cultura Popular, 1978. BARTRA, A. (ed.). Regeneración 1900-1918. Mexico City: ERA/SEP, 1986.

BUHLE, P. A Dreamer's Paradise Lost: Louis C. Fraina/Lewis Corey (1892-1953) and the Decline of Radicalism in the United States. Atlantic Highlands, New Jersey: Humanities Press, 1995.

CARR, B. El movimiento obrero y la política en México, 1910-1929. Mexico City: ERA, 1976.

Marxism and Communism in Twentieth-Century Mexico. Lincoln, London: University of Nebraska Press, 1992.

CHANG, J.; HALLIDAY, J. Mao: The Unknown Story. London: Jonathan Cape, 2005.

CLEMENTS, B. E. Bolshevik Feminist: The Life of Alexandra Kollontai. Bloomington and London: Indiana University Press, 1979.

CLISSOLD, S. (ed.). Soviet Relations with Latin America, 1918-1968. London: Oxford University Press, 1970.

ELLEY, G. Forging Democracy: The History of the Left in Europe, 1850-2000. Oxford, Great Britain: Oxford University Press, 2002.

GAA - Genaro Amezcua Archive. Emiliano Zapata to General Genaro Amezcua. Fondo VIII-2, file 4. Tlaltizapán, Morelos, 14 February 1918.

GÓMEZ, M. From Mexico to Moscow. Survey 55, London, Great Britain, October 1964.

KATZ, F. The Secret War in Mexico. Europe, The United States and the Mexican Revolution. Chicago: Chicago University Press, 1981.

KHEIFETS, V.; KHEIFETS, L. Michael Borodin: The First Comintern-emissary to Latin America. The International Newsletter of Historical Studies on Comintern, Communism and Stalinism, Manchester, Great Britain. II, n. 5/6, p. 340-367, 1994/95.

KRAUZE, E.; MEYER, J.; REYES, C. Historia de la Revolución Mexicana, 1924-1928. Mexico City: El Colegio de México, 1981.

LAZITCH, B.; DRCHKOVITCH, M. Lenin and the Comintern. Stanford, California: Hoover Institution Press, 1972. 
LOMNITZ, C. The Return of Comrade Ricardo Flores Magón. New York: Zone Books, 2014.

ORTIZ, R. Alexandra Kollontai en México: Diario y otros documentos. Veracruz, Mexico: Universidad Veracruzana, 2012.

PESTKOWSKI, S. Wspomnienia revolucjonisty. Lodz, Poland: Wydawnictwo Lodzkie, 1961.

PHILLIPS, C. Partidos socialistas en México y el desarrollo del partido comunista. RGASPI, fond 495, reg. 108, file 4. Madrid, 18 January 1920.

ROY, M. N. Memoirs. Bombay: Allied, 1964.

SHIPMAN, C. It Had to Be Revolution: Memoirs of an American Radical. Ithaca, N. Y.: Cornell University Press, 1993.

STERN, G. The Rise and Decline of International Communism. Great Britain: Edward Elgar, 1990.

ULDRICKS, T. J. Diplomacy and Ideology: The Origins of Soviet Foreing Policy. London and Beverly Hills: Sage, 1979.

WEINER, M. Comintern in Asia, 1919-39. In: MCDERMOTT, K.; AGNEW, J. The Comintern: A History of International Communism from Lenin to Stalin. New York: St. Martin's Press, 1997. pp. 158-190. 